10IKC-342

\title{
ILMENITE MACROCRYSTS IN PROTEROZOIC KIMBERLITES FROM SOUTHERN INDIA
}

\author{
Nayak* SS ${ }^{1}$, Ravi $\mathbf{S}^{2}$, Patel SC ${ }^{3}$, Akhtar $\mathbf{J}^{3}$ \\ ${ }^{1}$ Geological Survey of India, Kumaraswamy Layout, Bangalore 560078 \\ ${ }^{2}$ Geological Survey of India, Bandlaguda Complex, Hyderabad 500068, India \\ ${ }^{3}$ Department of Earth Sciences, Indian Institute of Technology, Powai, Mumbai 400076, India \\ "Email: nayak_gsi@yahoo.co.in
}

\section{INTRODUCTION}

Ilmenite, together with pyrope garnet and chrome diopside, is one of the common indicator minerals of kimberlite. Macrocrysts of ilmenite recovered from heavy mineral concentrates of kimberlites could be derived from a variety of sources. Most commonly they represent xenocrysts disaggregated from peridotite and eclogite, while some could be phenocrysts from the host kimberlite (Mitchell, 1977; Haggerty, 1991).

Ilmenite composition has been emphasised as an exploration guide for diamondiferous kimberlites. Reduced kimberlitic magma containing Mg-rich ilmenite would be expected to preserve diamond, whereas the presence of $\mathrm{Fe}^{3+}$ rich ilmenite could indicate oxidising processes that could destroy the diamond crystals. Mantle-derived ilmenites sometimes have Mn-rich composition, whose origin is controversial. Such ilmenites have been variably attributed to magmatic crystallization under reducing condition, metasomatic process or supergene process (Wyatt et al., 2004 and references therein). Kaminsky and Belousova (2009) reported Mn-rich ilmenite paragenetically related to diamond and formed under superdeep conditions of the lower mantle and/or transition zone.

In this investigation, we examine the compositions of discrete ilmenite macrocrysts recovered from heavy mineral concentrates of kimberlites from two prominent kimberlite fields of southern India: one diamondiferous and another almost barren. We report the occurrence of Mn-rich ilmenites in the barren field and discuss its implication.

\section{SOUTHERN INDIAN KIMBERLITES}

Kimberlites of southern India are confined to the Eastern Dharwar Craton, which is a typical granite-greenstone terrane with a gneissic basement of tonalite-trondhjemite-granodiorite composition known as the Peninsular Gneissic Complex. The kimberlites are distributed in four fields, viz. Wajrakarur Kimberlite Field (WKF), Narayanpet Kimberlite Field (NKF),
Raichur Kimberlite Field (RKF) and Tungabhadra Kimberlite Field (TKF) (Inset of Fig. 1).

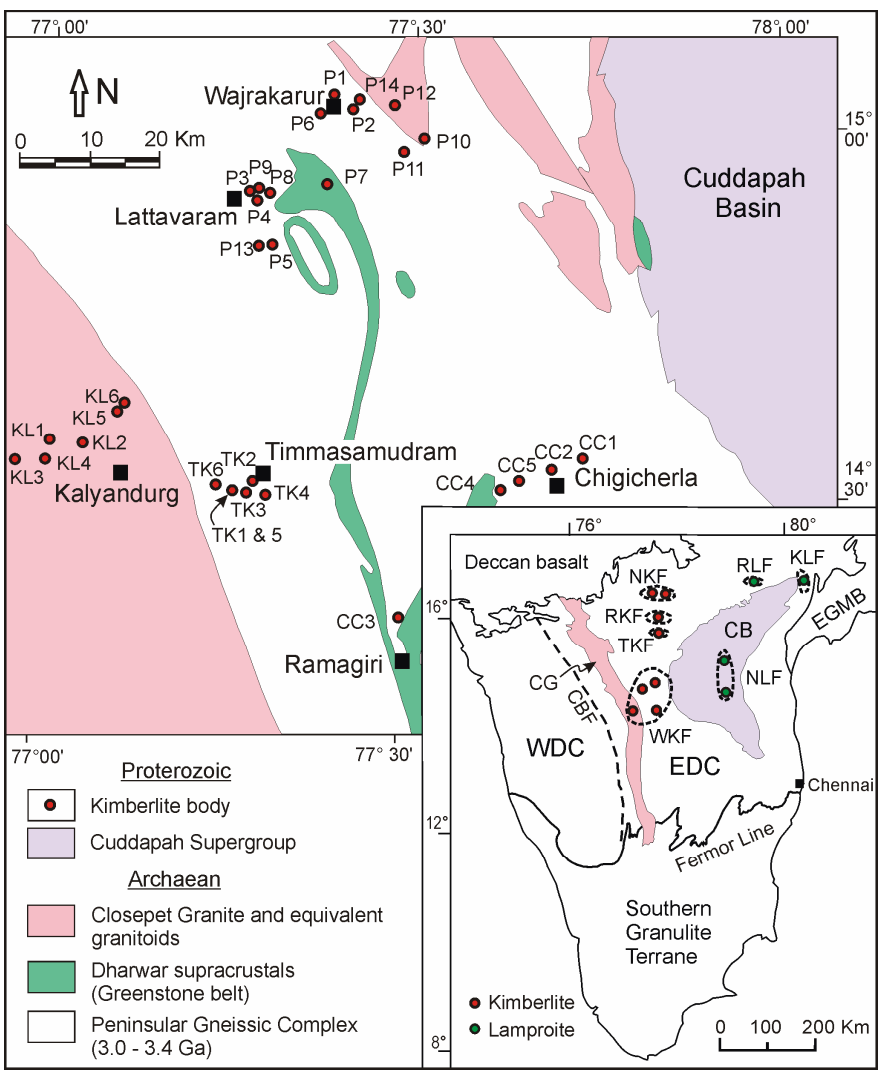

Fig.1. Generalised geological map of Wajrakarur Kimberlite Field (WKF). Inset shows sketch map of southern India with location of kimberlite and lamproite fields in Eastern Dharwar Craton (EDC). $\mathrm{CB}=$ Cuddapah Basin; $\mathrm{CBF}=$ Chitradurga Boundary Fault CG = Closepet Granite; KLF = Krishna Lamproite Field; NKF = Narayanpet Kimberlite Field; NLF = Nallamalai Lamproite Field; RLF $=$ Ramadugu Lamproite Field TKF $=$ Tungabhadra Kimberlite Field; WDC $=$ Western Dharwar Craton.

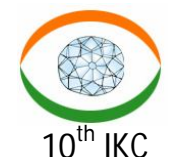




\section{$10^{\text {th }}$ International Kimberlite Conference-2012}

The WKF has a dimension of $\sim 80 \mathrm{~km} \times 70 \mathrm{~km}$, and is the largest kimberlite field of southern India (Fig. 1). It contains 45 intrusions, 31 of which are spread over four clusters, viz. Wajrakarur-Lattavaram (14 intrusions, P1-P14), Chigicherla (5 intrusions, CC1-CC5), Kalyandurg (6 intrusions, KL1KL6), and Timmasamudram (6 intrusions, TK1-TK6). Most of these kimberlites were discovered by the Geological Survey of India (GSI) during the last three decades. The other 14 intrusions (WK1-WK14) of the WKF have been recently discovered by M/s Rio Tinto Exploration, but their locations are undisclosed. The WKF kimberlites are usually small (surface area $<5$ ha) except for a few large bodies. The NKF occurs $\sim 200 \mathrm{~km}$ north of the WKF and is $\sim 60 \mathrm{~km} \times 30 \mathrm{~km}$ in extent (Fig. 2). The GSI has discovered 34 intrusions in the NKF distributed over four clusters, viz. Narayanpet (10 intrusions; NK1 to NK10), Maddur (11 intrusions; MK1 to MK11), Bhima (6 intrusions, BK1 to BK6) and Kotakonda (7 intrusions; KK1 to KK7). In addition, 29 intrusions occurring in two clusters have recently been discovered in the NKF by M/s De Beers India Pvt. Ltd. (Lynn, 2005). These kimberlites form the western extension of the NKF.

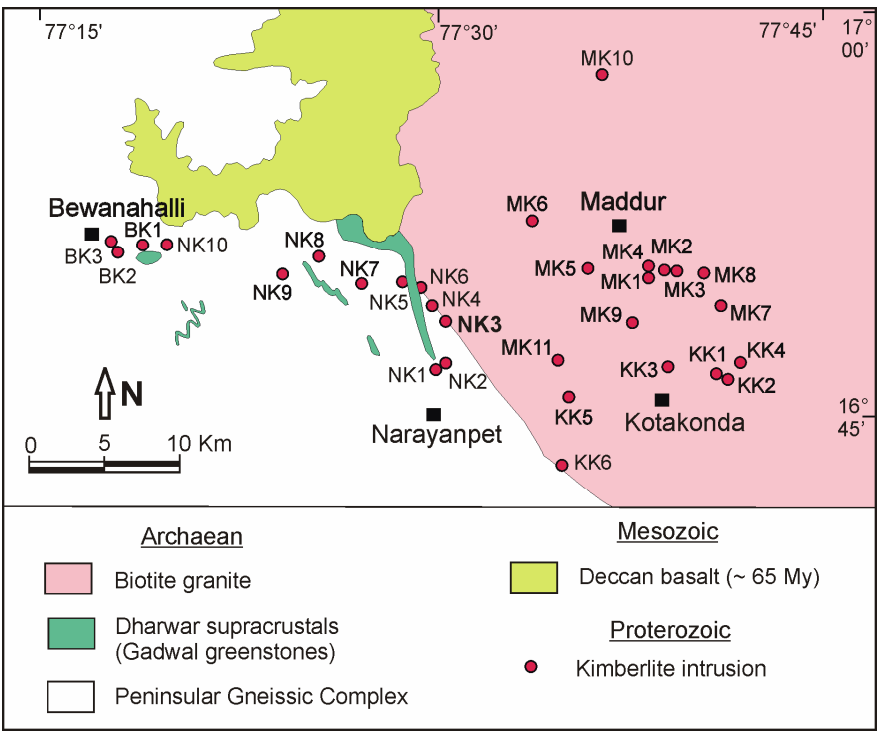

Fig.2. Generalised geological map of Narayanpet Kimberlite Field.

Most of the WKF kimberlites are poorly diamondiferous, whereas the NKF kimberlites are almost barren except a few diamonds reported by Lynn (2005) in surface heavy mineral samples from the kimberlites occurring southwest of Bewanahalli. The RKF contains 6 intrusions, out of which 3 have been tested for diamond incidence and noted to be barren. The TKF contains 6 intrusions, out of which 4 have been tested for diamond incidence, and 1 has been found to be diamondiferous.
Apart from the four kimberlite fields there are three lamproite fields in the EDC, viz. Krishna Lamproite Field, Nallamalai Lamproite Field and Ramadugu Lamproite Field. Available radiometric ages indicate that the southern Indian kimberlites erupted episodically in the Mesoproterozoic around $1100 \mathrm{Ma}$.

\section{KIMBERLITE INDICATOR MINERALS}

Weathered kimberlite and soil samples from a number of southern Indian kimberlites were processed for heavy mineral concentrates by the GSI, Hyderabad. The concentrates recovered from the WKF and TKF kimberlites include abundant of pyrope, chrome-diopside, ilmenite and spinel (Fig. 3), whereas those from the NKF are dominated by chrome-diopside with subordinate spinel and ilmenite. Appreciable quantities of garnets were recovered only from the NK3 and KK2 kimberlites of the NKF. The macrocrysts are usually $0.5-5 \mathrm{~mm}$ in size.

Ilmenite macrocrysts often show a whitish leucoxene coating. Ilmenites are abundant in the kimberlitic soil cover of KL1 and KL3 intrusions of the WKF where both macrocrysts and megacrysts $(1-2 \mathrm{~cm})$ are found.

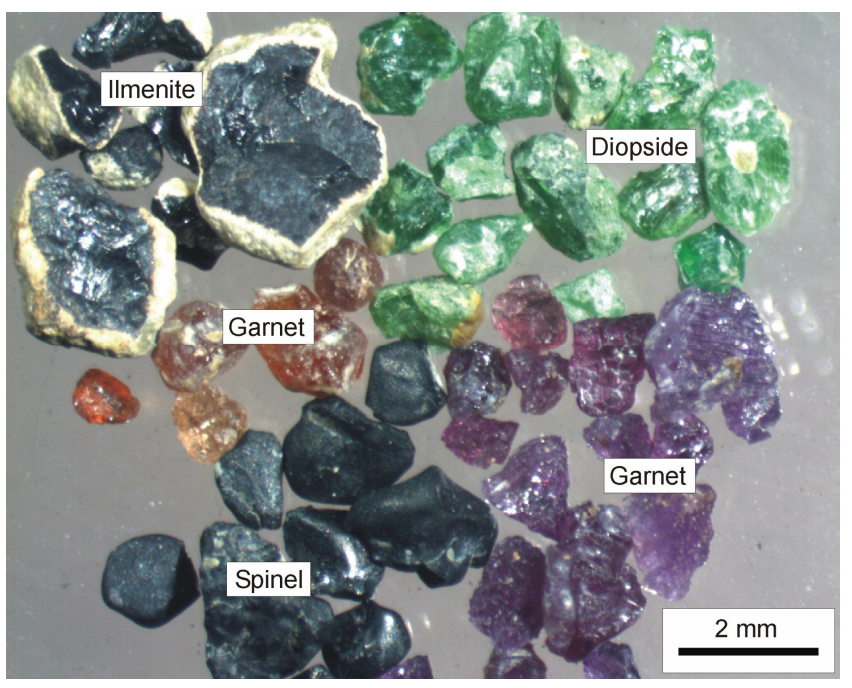

Fig.3. Photograph of indicator minerals from the heavy concentrate of a TKF kimberlite. Note the white coating on ilmenite macrocrysts.

\section{ILMENITE COMPOSITION}

\section{Discrete ilmenite macrocrysts}

Sastry et al. (2005) published a dataset of electron probe microanalyses of different kimberlite indicator minerals (garnet, Cr-pyrope, Cr-diopside, spinel and ilmenite) in the heavy mineral concentrates of a large number southern Indian

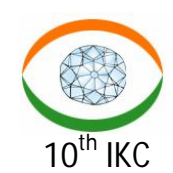




\section{$10^{\text {th }}$ International Kimberlite Conference-2012}

kimberlites, but did not attempt any interpretation of the data. In the present study compositional variations of concentrate ilmenites from the WKF and NKF (Sastry et al., 2005) are examined.

Although ilmenites in kimberlites are predominantly derived from mantle sources, crustal ilmenites are not uncommon as xenocrysts and need to be differentiated from the mantle population. Crustal sources of ilmenites include both igneous rocks (gabbro, norite, granite, and anorthosite) and metamorphic rocks (orthogneisses) that may occur in areas hosting kimberlite intrusions. From the dataset of Sastry et al. (2005), ilmenites with $[\mathrm{Fe} /(\mathrm{Fe}+\mathrm{Mg}+\mathrm{Mn})]>0.90$ were rejected since they are more likely to be of crustal origin. Furthermore, a few compositions of Sastry et al. (2005) were rejected on stoichiometric ground. The selected data set comprises 146 macrocrysts from the WKF and 81 macrocrysts from the NKF.

The ilmenite macrocrysts from the WKF and NKF show considerable differences in major element compositions. The WKF ilmenites have MgO content between 5.0 and $15.3 \mathrm{wt} \%$. Nearly one-third of the NKF ilmenites are Mg-poor with $<5.0$ wt $\% \mathrm{MgO}$, while the rest have 5.5-12.4 wt\% $\mathrm{MgO}$. The range of $\mathrm{MnO}$ content in the WKF ilmenites is $0.1-2.7 \mathrm{wt} \% \mathrm{MnO}$, whereas that in the NKF ilmenites is significantly wider with a dominance of high values $(0.1-14.9 \mathrm{wt} \% \mathrm{MnO})$. The NKF ilmenites are mostly $\mathrm{Cr}$-poor $\left(<2.5 \mathrm{wt} \% \mathrm{Cr}_{2} \mathrm{O}_{3}\right)$ compared to the WKF ilmenites (up to $6.2 \mathrm{wt} \% \mathrm{Cr}_{2} \mathrm{O}_{3}$ ) (Fig. 4).

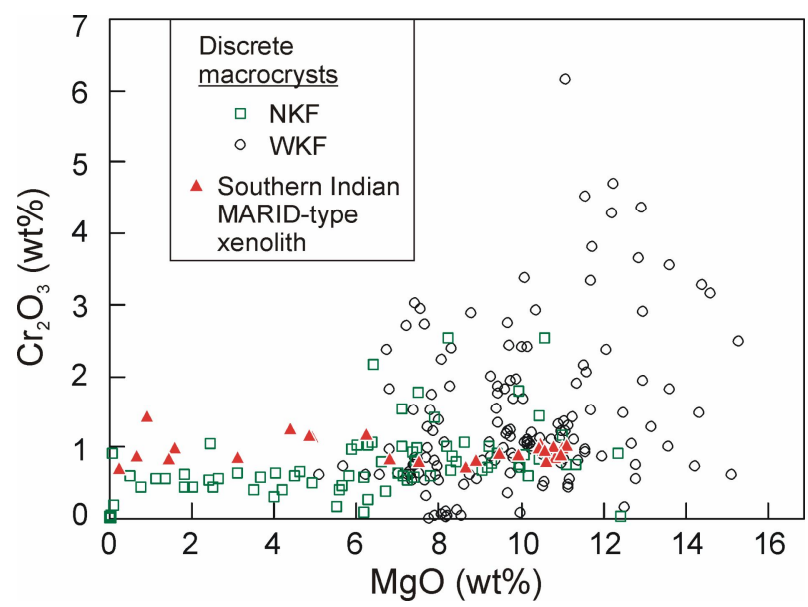

Fig.4. Composition of concentrate ilmenites in kimberlites from the NKF and WKF (Sastry et al., 2005) compared with that of ilmenite in MARID-type xenoliths from NKF and RKF kimberlites (Patel et al., 2012).

On $\mathrm{MgO}-\mathrm{TiO}_{2}$ plot, a sizable population of $\mathrm{NKF}$ ilmenites falls on the $\mathrm{MgO}$-poor side of the parabolic arc that is conventionally used as reference to discriminate kimberlitic ilmenites from non-kimberlitic ones (Fig. 5). On a ternary diagram representing molecular proportions of geikielite $\left(\mathrm{MgTiO}_{3}\right)$-ilmenite $\left(\mathrm{FeTiO}_{3}\right)$-pyrophanite $\left(\mathrm{MnTiO}_{3}\right)$, this population exhibits a trend broadly consistent with $\mathrm{Mg} \leftrightarrow \mathrm{Mn}$ substitution (Fig. 6). This population of low-Mg ilmenites shows significant compositional similarities with ilmenites in MARID-type xenoliths from some southern Indian kimberlites (Patel et al., 2012). This population of ilmenites is referred to as the MT-ilmenites (for MARID Type composition).

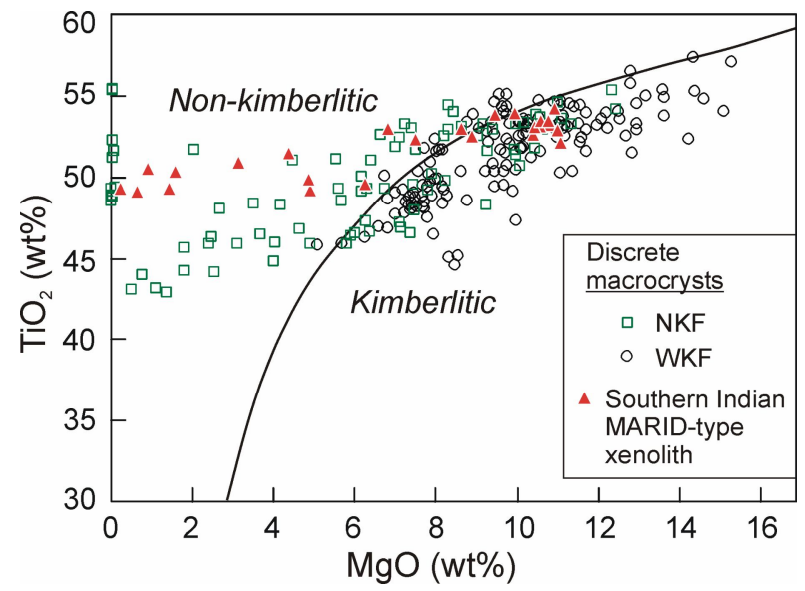

Fig.5. $\mathrm{TiO}_{2}-\mathrm{MgO}$ plot of ilmenite in kimberlites from the NKF and WKF. Data sources same as in Fig. 4. Parabolic arc dividing kimberlitic and non-kimberlitic ilmenites after Wyatt et al. (2004).

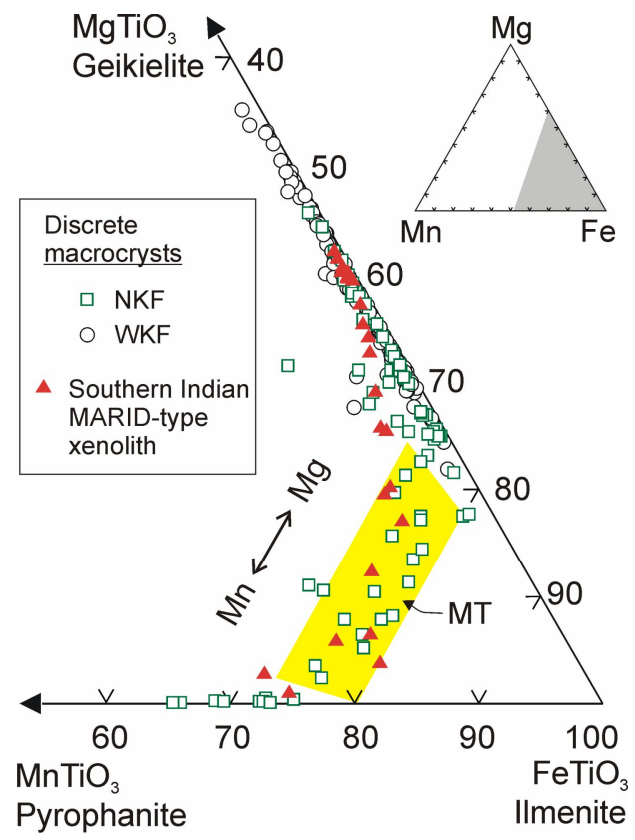

Fig.6. $\mathrm{MgTiO}_{3}-\mathrm{FeTiO}_{3}-\mathrm{MnTiO}_{3}$ plot of concentrate ilmenites in kimberlites from the NKF and WKF. Data sources same as in Fig. 4. MT is the field M-type ilmenites from the NKF.

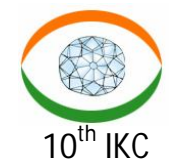




\section{$10^{\text {th }}$ International Kimberlite Conference-2012}

Stoichiometrically calculated $\mathrm{Fe}_{2} \mathrm{O}_{3}$ content in the ilmenite suites is low and the range is similar for both WKF and NKF ilmenites (Fig. 7). On the $\mathrm{Fe}_{2} \mathrm{O}_{3}-\mathrm{MgO}$ diagram of Gurney and Zweistra (1995), the WKF ilmenites fall in the fields of high to intermediate and marginal preservation of diamonds which is consistent with the diamondiferous nature of the WKF. However, although the NKF is almost barren, most of their concentrate ilmenites fall in the fields of intermediate and marginal preservation of diamonds.

On the plot of $\mathrm{MgTiO}_{3}-\mathrm{FeTiO}_{3}-\mathrm{Fe}_{2} \mathrm{O}_{3}$, the population of MT-ilmenites from the NKF shows a trend of increasing $\mathrm{Fe}_{2} \mathrm{O}_{3}$ with decreasing $\mathrm{MgTiO}_{3}$ (Fig. 8A). The same population shows slight increase in $\mathrm{MnTiO}_{3}$ with decreasing $\mathrm{FeTiO}_{3}$ at nearly constant $\mathrm{Fe}_{2} \mathrm{O}_{3}$ (Fig. 8B). The MT-ilmenites have somewhat higher content of $\mathrm{Fe}_{2} \mathrm{O}_{3}$ than the ilmenites of the southern Indian MARID-type xenoliths.

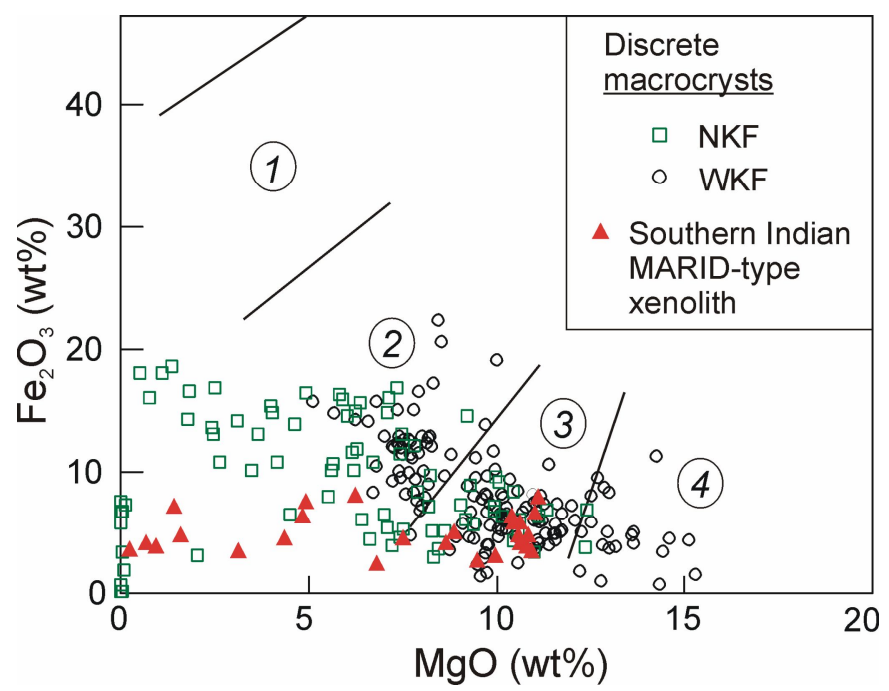

Fig.7. Concentrate ilmenites in kimberlites from the NKF and WKF on the $\mathrm{Fe}_{2} \mathrm{O}_{3}-\mathrm{MgO}$ diagram of Gurney and Zweistra (1995). Data sources same as in Fig. 4. Diamond preservation fields: $l=$ High Fe, low $\mathrm{Mg}$, no preservation; 2 = marginal preservation; $3=$ Intermediate case, $92 \%$ tetrahexahedrons; $4=$ High $\mathrm{Mg}$, low Fe, ultimate preservation, late stage growth.

\section{Ilmenite in Kalyandurg kimberlites}

Kimberlite rock samples from the Kalyandurg cluster of the WKF commonly contain ilmenite macrocrysts, which vary in shape from subrounded (Fig. 9) to rectangular (Fig. 10). Ilmenite macrocrysts in the KL3 kimberlite often show exsolution lamellae of haematite and one such macrocryst has been studied for its compositional characteristics. The macrocryst is a deformed one occurring in an undeformed kimberlite. The grain exhibits two-stage growth marked by distinct core and rim (Fig. 10).

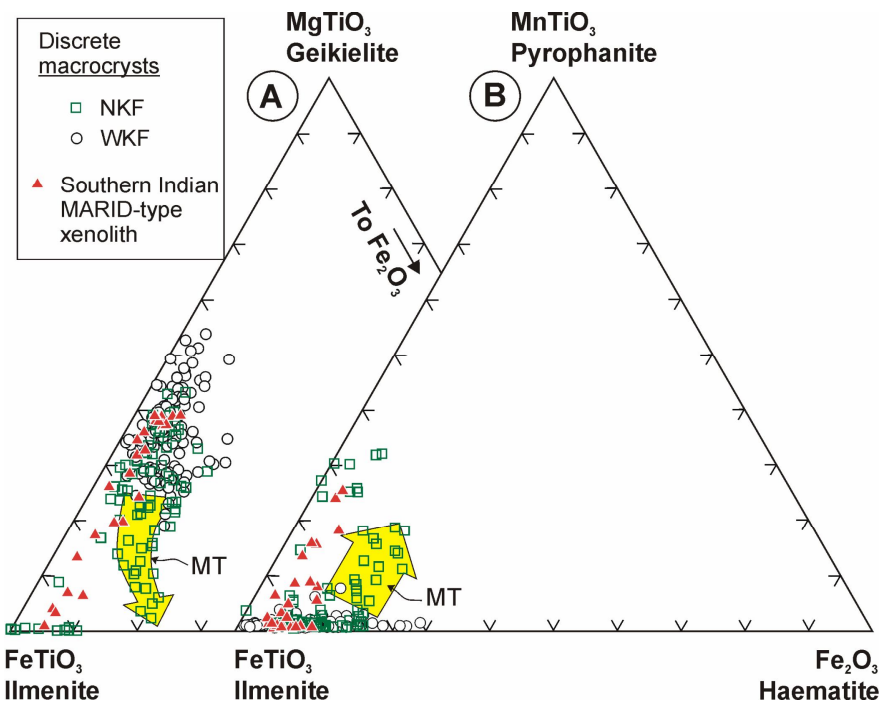

Fig.8. Composition of concentrate ilmenites in kimberlites from the $\mathrm{NKF}$ and WKF on: (A) $\mathrm{MgTiO}_{3}-\mathrm{FeTiO}_{3}-\mathrm{Fe}_{2} \mathrm{O}_{3}$ plot; and (B) $\mathrm{MnTiO}_{3}-\mathrm{FeTiO}_{3}-\mathrm{Fe}_{2} \mathrm{O}_{3}$ plot. Yellow arrows show a population of MT-ilmenites from the NKF with trend of decreasing $\mathrm{MgTiO}_{3}$ in (A) and increasing $\mathrm{MnTiO}_{3}$ in (B). The curved nature of arrow in (A) denotes increasing $\mathrm{Fe}_{2} \mathrm{O}_{3}$ with decreasing $\mathrm{MgTiO}_{3}$.

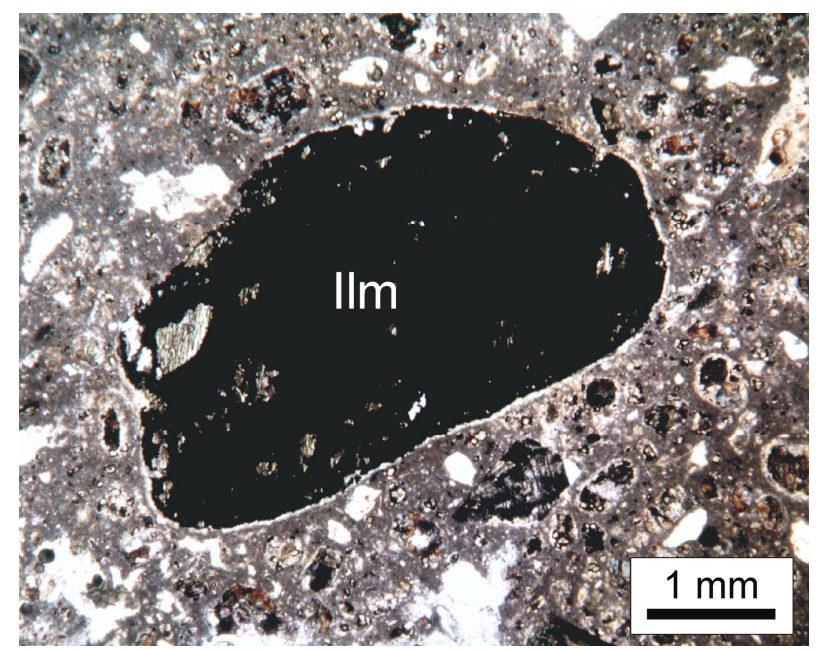

Fig.9. Photomicrograph of KL1 kimberlite of WKF in transmitted plane polarized light showing ilmenite (Ilm) macrocryst. The groundmass comprises fine-grained aggregate of serpentine and diopside. Phenocrysts and microphenocrysts of olivine pseudomorphed by serpentine, magnetite and sphene are common in the rock.

The core of the studied grain is Mg-rich ilmenite (17-20 wt $\% \mathrm{MgO} ;<1 \mathrm{wt} \%$ each of $\mathrm{MnO}$ and $\mathrm{Cr}_{2} \mathrm{O}_{3}$ ) with exsolution lamellae of titanohaematite (7-10 wt $\% \mathrm{MgO} ; 1-3 \mathrm{wt} \% \mathrm{MnO}$; 4-7 wt $\% \mathrm{Cr}_{2} \mathrm{O}_{3}$ ). The rim is Mg-poor ilmenite $(<2 \mathrm{wt} \% \mathrm{MgO}$; $4-5 \mathrm{wt} \% \mathrm{MnO}$ and $<0.5 \mathrm{wt} \% \mathrm{Cr}_{2} \mathrm{O}_{3}$ ) with exsolution lamellae 


\section{$10^{\text {th }}$ International Kimberlite Conference-2012}

of haematite $(2-4 \mathrm{wt} \% \mathrm{MgO} ;<1$ wt\% $\mathrm{MnO} ; 2-3$ wt $\%$ $\mathrm{Cr}_{2} \mathrm{O}_{3}$ ). The ilmenite host contains $\mathrm{Nb}_{2} \mathrm{O}_{5}$ in the range of $0.1-$ $0.3 \mathrm{wt} \%$, whereas the exsolution lamellae of titanohaematite and haematite contain much less or no $\mathrm{Nb}$.

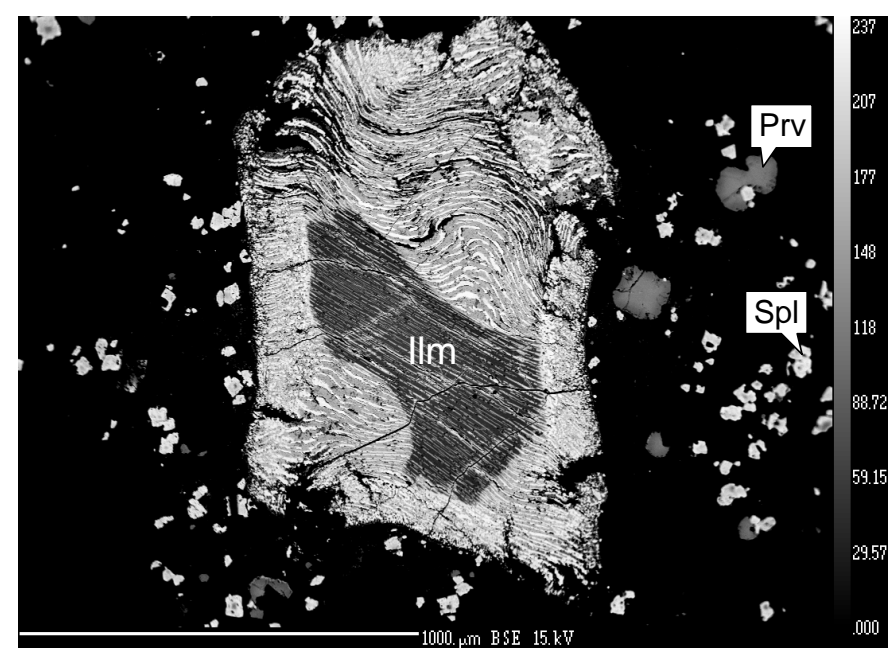

Fig.10. Back-scattered electron image of a kimberlite from the KL3 intrusion of the WKF showing deformed macrocryst of ilmenite (Ilm). Spinel ( $\mathrm{Spl}$ ) and perovskite (Prv) occur in the groundmass. Bar scale is 1000 micron long.

Microscopic study of the ilmenite macrocryst in reflected light shows that the exsolution lamellae of titanohaematite and haematite are weakly anisotropic. The lamellae in the core of the ilmenite are straight and undeformed, whereas the rim zone records deformation in the form of crenulations of exsolution lamellae as well as the host. Since the kimberlite is undeformed, the ilmenite macrocryst must have undergone exsolution and high-temperature deformation before being incorporated in to the kimberlite magma. Thus, the macrocryst is a xenocryst rather than a phenocryst.

Some unidentified phases such as $\mathrm{Ca}-\mathrm{Fe}$ titanate and $\mathrm{Ca}-$ $\mathrm{Ba}$ titanate with highly variable composition occur locally in the rim zone of the ilmenite. These are most likely secondary products formed by reaction of ilmenite with kimberlitic fluid. Study of some other ilmenite macrocrysts in Kalyandurg kimberlites shows that the grains are rimmed by perovskite, which also might have formed by such reaction.

\section{DISCUSSION}

Concentrate ilmenites from the WKF show on the average, elevated content of $\mathrm{Cr}_{2} \mathrm{O}_{3}$ compared to those from the NKF. Such high $\mathrm{Cr}_{2} \mathrm{O}_{3}$ content is typical of 'kimberlitic ilmenites' described by Haggerty (1975) and Wyatt et al. (2004).
A sizable population of concentrate ilmenites of Mn-rich composition from the NKF kimberlites shows compositional similarities with ilmenites in MARID-type xenoliths from some southern Indian kimberlites. These ilmenites are therefore interpreted to have been derived from such xenoliths. Such ilmenites are absent in the discrete macrocryst suites of the WKF kimberlites. This leads us to believe that the mantle wall-rocks beneath the almost barren NKF underwent extensive MARID-type metasomatism relative to those beneath the diamondiferous WKF. Detailed microtextural and trace element studies of the discrete ilmenites are required to explore the role of metasomatic and supergene processes on their compositional attributes.

A deformed xenocryst of ilmenite in a WKF kimberlite shows $\mathrm{Mg}$-rich core and $\mathrm{Mg}$-poor rim. This implies that discrete ilmenite macrocrysts of both $\mathrm{Mg}$-rich and $\mathrm{Mg}$-poor compositions recovered from kimberlite concentrates could represent xenocrysts in the kimberlites.

\section{REFERENCES}

Gurney, J.J. and Zweistra, P. (1995) The interpretation of the major element compositions of mantle minerals in diamond exploration. Jour. Geochem. Expl., v.53, pp.293-309.

Haggerty, S.E. (1975) The chemistry and genesis of opaque minerals in kimberlite. In: Ahrens, L.H., Dawson, J.B., Duncan, A.R., Erlank, A.J. (Eds.), Proc. 1st Int. Kimb. Conf., Physics Chem. Earth, v.9, pp.195-307.

Haggerty, S.E. (1991) Oxide mineralogy of the upper mantle. In: Lindsley, D.H. (Ed.), Oxide Minerals. Mineral. Soc. America Reviews in Mineralogy, v.25, pp.355-416.

Kaminsky, F.V. and Belousova, E.A. (2009) Manganoan ilmenite as kimberlite/diamond indicator mineral. Russian Geol. Geoph., v.50, pp.1212-1220.

Lynn, M. (2005) The discovery of kimberlites in the Gulbarga and Raichur districts of Karnataka. Group discussion on "Kimberlites and Related Rocks of India", Geological Society of India, Bangalore, pp.48-49.

Mitchell, R.H. (1977) Geochemistry of magnesian ilmenites from kimberlites in South Africa and Lesotho. Lithos, v.10, pp.29-37.

Patel, S.C., Ravi, S. and Thakur, S.S. (2012). MARID-type xenoliths in Proterozoic kimberlites from southern Indian: Implications on mantle metasomatism. $10^{\text {th }}$ IKC extended abstract no. 37 .

Sastry, C.A., Rao, G.R., Prasad, G.J.S. and Reddy, V.A. (2005) Electron probe microanalysis of indicator minerals from kimberlites of Andhra Pradesh and Karnataka - basic data. Geol. Survey India Bull. Series C, no.6, 282p.

Wyatt, B.A., Baumgartner, M., Anckar, E. And Grutter, H. (2004) Compositional classification of "kimberlitic" and "nonkimberlitic” ilmenite. Lithos, v.77, pp.819-840.

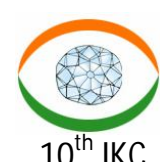

